\title{
Article \\ Pre-Load Effect on CFRP-Confinement of Concrete Columns: Experimental and Theoretical Study
}

\author{
Francesco Micelli ${ }^{1, *(\mathbb{D}}$, Alessio Cascardi ${ }^{2}(\mathbb{D})$ and Maria Antonietta Aiello ${ }^{1}(\mathbb{C}$ \\ 1 Department of Innovation Engineering, University of Salento, via per Monteroni, 73100 Lecce, Italy; \\ antonietta.aiello@unisalento.it \\ 2 ITC-CNR, Construction Technologies Institute, Italian National Research Council, 70124 Bari, Italy; \\ alessio.cascardi@itc.cnr.it \\ * Correspondence: francesco.micelli@unisalento.it
}

Citation: Micelli, F.; Cascardi, A.; Aiello, M.A. Pre-Load Effect on CFRP-Confinement of Concrete Columns: Experimental and Theoretical Study. Crystals 2021, 11, 177. https://doi.org/10.3390/ cryst11020177

Academic Editor: Jose Garcia

Received: 15 January 2021

Accepted: 5 February 2021

Published: 10 February 2021

Publisher's Note: MDPI stays neutral with regard to jurisdictional claims in published maps and institutional affiliations.

Copyright: (c) 2021 by the authors. Licensee MDPI, Basel, Switzerland. This article is an open access article distributed under the terms and conditions of the Creative Commons Attribution (CC BY) license (https:// creativecommons.org/licenses/by/ $4.0 /)$.

\begin{abstract}
The axial compression strength of concrete columns has been proved to be significantly enhanced by external confinement. In this perspective, the use of Fiber-Reinforced Polymers (FRPs) has been extensively studied. In practical applications, the FRP-confinement is installed on loaded columns, which can already be significantly deformed, while theoretical models neglect this aspect. This paper concerns a new experimental investigation on the possibility that a pre-existing axial load affects the FRP-confinement of concrete. The research program also aimed at the development of a new analysis-oriented-model for the prediction of the compressive strength of FRP-jacketed concrete columns, depending on the level of the axial load, acting before the confinement. For this purpose, series of small-scale concrete cylinders were first loaded, then confined with Carbon FRP, and finally subjected to destructive pure axial compression tests. Four different levels of pre-existing loads were simulated, including the un-loaded condition.
\end{abstract}

Keywords: FRP; column; analysis-oriented model; preload 1

\section{Introduction}

In the last years, a large diffusion of FRP composites has been experienced in the civil engineering field. This was mainly due to the scientific studies, focused on their mechanical behavior, that were conducted in the last decades. For these reasons, the large demand of Fiber-Reinforced Polymers (FRPs) increased in the field of structural strengthening [1-5]. Proven advantages are mainly recognizable in tensile properties, weight/strength ratio, durability, absence of galvanic corrosion, and ease of installation. One of the most successful applications of FRPs is the external confinement of vertical elements subjected to high compressive and/or shear loads, i.e., columns, piles, poles, etc. In this role, these structural members are subjected to axial load that induces longitudinal and transversal deformation at the same time. On the contrary, FRP-confinement results in a hydrostatic pressure which acts in opposition to the lateral dilatation, improving the axial strength at the same time. In real cases, columns are already loaded when the FRP-jacket is applied. The common design formulas consist in empirical equations obtained by means of regression analysis of a test database, mostly referring to un-loaded specimens (see [6-17]). In cases of infrastructures and even large-framed buildings (see [18]), the level of stress in the columns due to the dead loads is important. In real applications, it is impossible to significantly reduce this stress state by means of active shoring. For these reasons, it appears meaningful to verify if the existing analytical models may result consistent with the real mechanical behavior and how much the design equations may be considered conservative.

According to the aforementioned purposes, the present paper shows the results of an experimental program regarding pure axial compression tests of small-scale concrete cylinders, which were confined by Carbon FRP (CFRP) jackets under different pre-loading 
conditions. The main goal consists in comparing the stress-strain curves of the un-loaded and confined with the pre-loaded and confined samples, in order to understand the influence of the pre-load level on the CFRP-confinement effectiveness. In this perspective, different loads (in proportional ratio to the ultimate load of the un-confined concrete) were imposed on a series of samples, and they then were confined with CFRP-jacket, by using a manual wet lay-up method. Axial stress and strain values were recorded as same as the hoop strain values. Finally, the experimental results were computed to implement a new analysis-oriented-model (AOM) able to catch how the different pre-load levels affect the confining action and the whole mechanical response of confined concrete.

\section{Background}

This section reports an extensive experimental database collected by the authors from the published scientific literature. The studies in [19-66] report the results of compression tests on FRP-confined specimens collected and analyzed by the authors. The specimens had different sizes, cross-sections, concrete classes, confining fibers type, and confinement schemes, for a total of more than 2400 tests. Various important parameters of the FRPconfinement were analyzed in the past decades: cross-sectional type, compression strength of the unconstrained concrete, fiber type, number of FRP-layers and their thickness, presence of internal reinforcement within the concrete sample, confinement technique, presence or absence of preload on the column prior to the execution of the confinement itself, etc. All of these factors affect the results of compression tests more or less significantly, but only a few studies are related to the effect of the pre-load.

In general, the database encloses concrete samples with a compression strength ranging between 6.2 and $200 \mathrm{MPa}$. The characteristic dimension (the outer diameter for solid circular or hollow cross-section, the outer side of solid square or rectangular samples, and minor axis for the elliptical cross-section) ranged from 47 to $610 \mathrm{~mm}$, and the ratio between the height and the characteristic size was from 1 to 10 . The fibers mainly used were carbon fibers $(\mathrm{C})$, glass fibers $(\mathrm{G})$, and aramid fibers $(\mathrm{A})$. In addition to these, poliparafenilenbenzobis-oxazolo (PBO) fibers and other synthetic materials such as polyEthylene naphthalate, polyethylene terephthalate, and polycinyl chloride (PEN, PET, and PVC, respectively) have been used in some experiments. Most experiments were conducted using specimens that were not reinforced with internal longitudinal and/or transverse steel reinforcement. Compared to the entire population of available results, only a few studies report specimens that were tested as reinforced concrete columns, using internal steel bars and stirrups (e.g., [28-37,41-43]). All collected experimental outcomes have been related to the index between the elastic modulus of the fibers $\left(\mathrm{E}_{\mathrm{f}}\right)$ on the concrete $\left(\mathrm{E}_{0}\right)$ and the geometrical ratio of reinforcement $\left(\left(4 n t_{f}\right) / D\right)$, where $\mathrm{D}$ is the equivalent diameter of the cross section, $\mathrm{n}$ is the number for FRP layers, and $t_{f}$ is the thickness of each FRP layer, typically referred to dry fibers. In such way, the effectiveness of the FRP-confinement, represented by the ratio between the confined and unconfined strength $\mathrm{f}_{\mathrm{cc}} / \mathrm{f}_{\mathrm{c} 0}$, can be easily related to the concrete grade and number of fibers (see Figure 1). The tridimensional diagram in Figure 1, obtained from the analysis of many data, demonstrates that FRP-confinement significantly increases the compressive strength of the unconfined concrete $\left(\mathrm{f}_{\mathrm{c} 0}\right)$ as soon as the elastic modulus of the fiber increases with respect to the modulus of concrete. On the other hand, the increase of the compressive strength of FRP-confined concrete $\left(f_{\mathrm{cc}}\right)$ is lower for a bigger diameter of the cross-section and a higher class of concrete. In other words, the effectiveness of the FRP confinement increases as the mechanical properties of the fibers increase, the concrete grade decreases, the number of FRP layers increases, and the transverse dimensions of the cross section decrease. Although the pre-load effect has been studied recently [59-66], the conclusions were not always consistent each other. The conclusions are not always comparable since the ratio between the concrete grade and tensile properties of FRP may be very different, as starting data. 


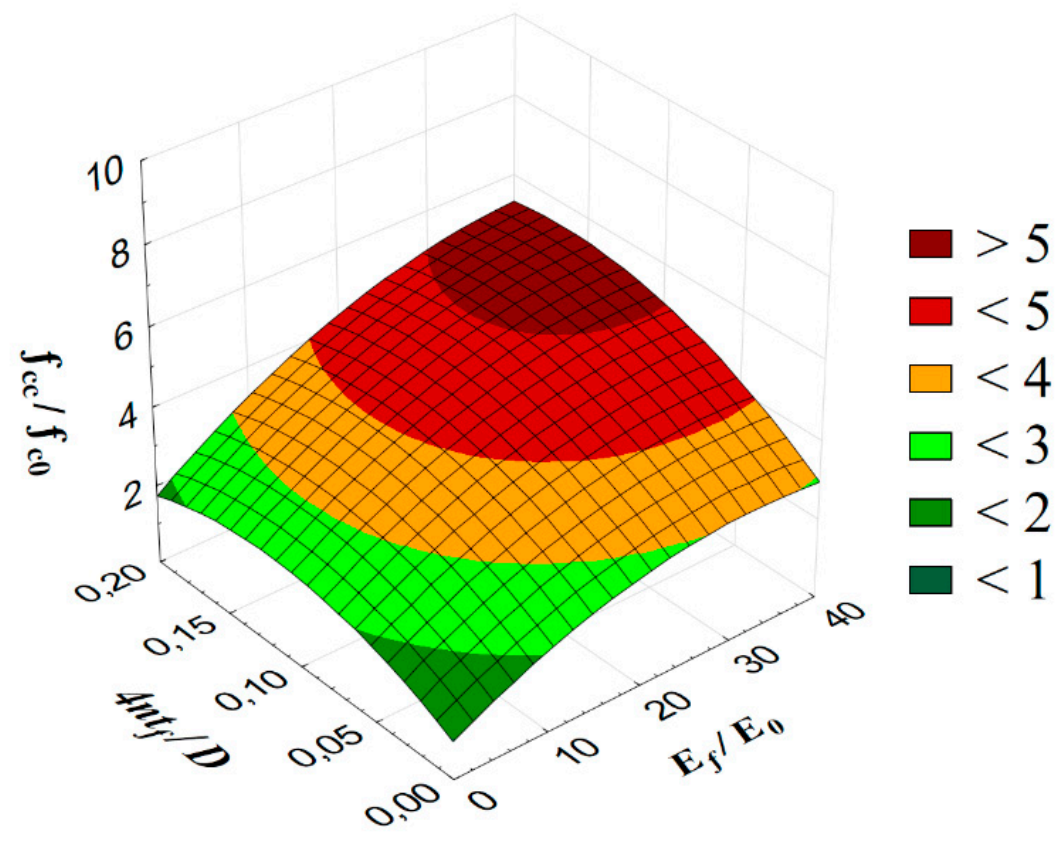

Figure 1. Color map of the effectiveness of the FRP-confinement of concrete.

\subsection{Available Studies on Pre-Load Effect}

Eight CFRP jacketed circular RC column specimens, prior loaded up to failure without external CFRP confinement, were tested under monotonic compression stresses in 1999 (see [56]). The effects of various parameters, such as the concrete strength, longitudinal steel reinforcement, steel stirrups, steel corrosion, and concrete damage, were investigated. It was conveyed that the original strength was totally re-established in the case of damaged columns. Further experimental results are provided in [57]. After the pre-damaging process, the specimens, with low compressive strength, were tested. The CFRP-strengthened specimens behaved similarly as the strengthened undamaged specimens, in terms of peak strength, stiffness, and deformability. The results illustrated in [58] highlight the effect of the pre-damage level and winding angle $\left(45^{\circ}, 60^{\circ}\right.$, and $\left.90^{\circ}\right)$ of the FRP-wrapping on the uniaxial compressive behavior of concrete specimens. It was shown that the confining pressure provided by FRP strongly helped to limit the cracks opening and enhance the confined compression strength of the pre-damaged specimens. The final strength was almost equal to that of the un-damaged concrete cylinders. A numerical investigation is presented in [59], where the effectiveness of FRP-confinement was demonstrated to increase when the compressive strength of the un-confined concrete decreases. However, a small reduction of the compressive strength appeared to be related to the rise of the pre-load level. In [60], the concrete specimens were loaded until a level equal to $77 \%$ of the unconfined strength prior to FRP-strengthening. Due to this load, the specimens were cracked, but, after the compression tests, the comparison with control specimens revealed that the pre-loading condition was not significantly influencing on the mechanical response in terms of peak strength. The damage prior to the FRP-retrofitting (due to induced axial stress equal to the $77 \%$ of the un-confined concrete) of small specimens was tested by the authors of [60]; the observed effects did not result so meaningful. The results reported in [61] appear controversial, where an approximately $40 \%$ sustained load level was applied before the application of FRP. CFRP-wrapped cylindrical concrete specimens exhibited strength increase when subjected to sustained pre-load. The increase was higher for very low strength concrete. The strength increase was attributed to the fact that, under sustained loading, CFRP becomes active earlier. Pre-damaged concrete specimens with square cross section are confined with CFRP sheets in [62], and a reduction in the axial stiffness is measured. This is reasonable as micro cracking is produced during the pre-loading phase, 
inside the concrete matrix. At the same time, the confinement effectiveness of the preloaded specimens was remarkably less than the control specimens with no pre-load. It is important to remark that in this study pre-damaged specimens were equipped with three layers of CFRP while un-damaged specimens with just one layer. An experimental program involving concrete cylinder specimens was carried out to investigate the type of FRP pattern and the presence of concrete damage prior to FRP-retrofitting in [63]. It was found that crack location and crack length affect differently the compressive strength of concrete. In particular, loss in compressive strength was more evident in specimens with crack located in the center than in specimens with crack at the edge. In 2014, a set of 36 concrete samples with square cross-section was tested in compression at different loading rates [64]. It was convened that sustained loading caused a loss in axial capacity when low-strength concrete was adopted, and the pre-load effect was less significant for concrete samples poured with an ordinary strength mix. An experimental and theoretical study on the FRP-confinement of concrete with pre-loading is reported in [65]. Test results and numerical simulations were implemented for the analysis-oriented-model assessment. A parametric analysis clearly showed that the pre-load produces a small reduction of the axial strength. An increased number of layers appeared to mitigate the small detrimental effects of pre-loading. By assuming the same FRP-confinement, the decrease of compressive strength due to pre-loading was found to be less for medium-strength concrete (28.8 $\mathrm{MPa}$ of compressive strength) compared to the low-strength one (21.1 MPa of compressive strength). Twenty-four HSC (high strength concrete) cylinders, with compressive strength of $50 \mathrm{MPa}$, were loaded in compression until a certain damaged level and then repaired by using steel wraps, as described in [66]. The experimental investigation resulted in an increased compressive strength for damaged concrete (pre-loading levels about $50 \%$ and $100 \%$ of the compressive strength of the unconfined concrete), while a dramatic strength reduction was recorded for specimens that were preloaded reaching an axial strain level higher than the peak strain of the unconfined concrete (i.e., $\sim 0.4 \%$ ).

\subsection{Research Significance}

Critical reviews in the existing scientific literature, related to the mechanical behavior of FRP-confined concrete, indicate that there are several aspects on which more investigation is required. These variables include, among others, the pre-load effect on the effectiveness of the FRP-confinement. For this reason, a specific experimental program was planned and is presented in the next paragraphs. It was targeted on the study of the mechanical behavior of FRP-confined concrete, strengthened with and without pre-load. According to Figure 1, if the cross-section and FRP-jacket dimension remain unchanged, as well as the mechanical properties of the fiber, the effectiveness of the FRP-confinement is expected to be influenced by the pre-load level because of its capacity to affect the compressive strength of the un-confined concrete, prior to strengthening. Two opposing trends are expected in this scenario: the first, which is immediately clear, regards the strength reduction of pre-cracked concrete and the second regards the effectiveness of the FRP-confinement on a concrete weakened because of the pre-loading condition. The first effect would lead to a reduction of the final compressive strength with respect to the un-loaded condition, as soon as the pre-load level would increase. On the other hand, the confinement is expected to be more effective since the E0 of the pre-cracked concrete is reduced. The first effect is expected to prevail, according to the existing literature results. The results presented herein aim to provide an active contribution to this ongoing engineering problem.

\section{Experimental Program and Results}

The experimental campaign was planned to test small-scale unreinforced concrete cylinders confined by unidirectional CFRP. The composite system was made up of an epoxy matrix and carbon fibers unidirectional sheets with fibers placed at $90^{\circ}$ with respect to the axis of the columns. The confinement was applied after imposing three different levels 
of pre-load; a series of unloaded cylinders was also strengthened with the same scheme and tested as a control series. Thus, 25 cylindrical specimens having a diameter of $100 \mathrm{~mm}$ and height of $200 \mathrm{~mm}$ were tested. In particular, five samples were left unconfined (" $\mathrm{U}$ "); five were CFRP-confined with null pre-load level ("P0"); and three sets of five specimens, named "P20", "P50", and "P80", were confined after imposing a pre-load level equal to $20 \%, 50 \%$, and $80 \%$ of the unconfined concrete compression strength, respectively.

\subsection{Materials and Methods}

The mechanical characterization of concrete was done by uniaxial compression tests on the five unconfined cylindrical specimens according to [67]. The specimens were instrumented by using two radial strain-gauges ( $3 \mathrm{~mm}$ long), located at the mid-high of the specimen and circumferentially oriented. The specimens were tested by a vertical hydraulic press (nominal compression rate of $3000 \mathrm{kN}$ ) with a load control of $0.05 \mathrm{MPa} / \mathrm{s}$. The test set-up also included the use of a 50-ton load-cell; two Linear Variable Displacement Transducers (LVDT) with a total stroke of $50 \mathrm{~mm}$ were used to measure the axial shortening, necessary to compute the axial deformation of the specimens. All transducers were connected to a data logger and a computer for the data processing and acquisition. Figure 2 shows the average axial stress-deformations curves computed from the data of the five unconfined specimens. It was found that the concrete compressive strength was $23.76 \mathrm{MPa}$, the axial and radial ultimate deformation values were $7.2 \%$ and $1.5 \%$, respectively; the longitudinal elastic modulus (tangent modulus) was about $14 \mathrm{GPa}$; and the Poisson ratio was equal to 0.30 . A low concrete grade was chosen in this study to reproduce the largest part of the real strengthening scenarios.

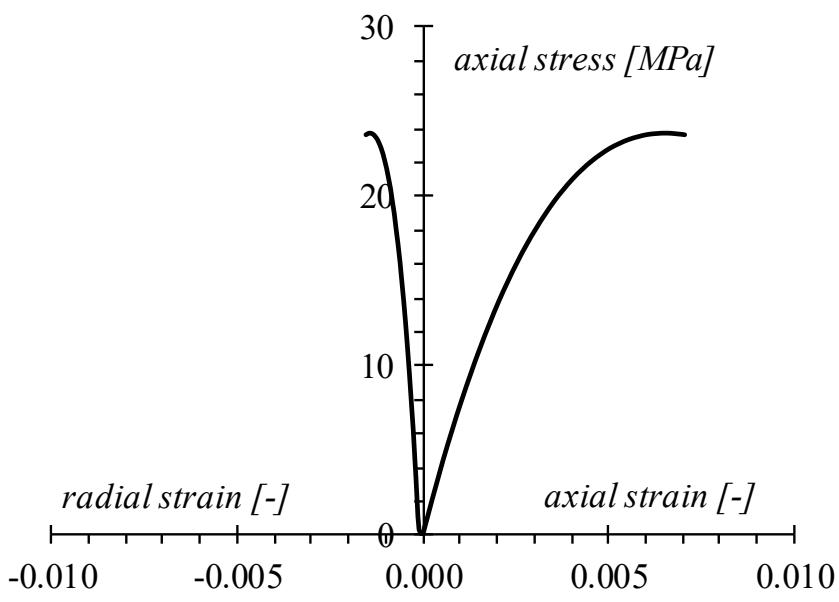

Figure 2. U-series stress-strain behavior (curve was averaged from five specimens).

The mechanical properties of the Carbon Fiber Reinforced Polymer (CFRP) were obtained by conducting tensile tests under displacement control with a rate of $0.02 \mathrm{~mm} / \mathrm{min}$, according to [68]. A two-component epoxy resin was used as adhesive and matrix. A fiber strip $100 \mathrm{~mm}$ long, $0.164 \mathrm{~mm}$ thick, and $25 \mathrm{~mm}$ wide was cured and cut. Table 1 summarizes the tensile properties of the CFRP coupons, including the ultimate strength $\mathrm{ff}$, the deformation at rupture $\varepsilon_{\mathrm{f}}$, and the elastic modulus $E_{f}$; mean values $(\mu)$, standard deviation $(\sigma)$, and Coefficient of Variation $(\mathrm{CoV})$ are listed below.

Table 1. CFRP tensile test results.

\begin{tabular}{cccc}
\hline Label & $f_{f}$ (MPa) & $\varepsilon_{f}(-)$ & $E_{f}(\mathbf{G P a})$ \\
\hline$\mu$ & 2542.80 & 0.012 & 212.15 \\
$\sigma$ & 560.07 & 0.001 & 53.49 \\
$\operatorname{CoV}$ & $22 \%$ & $10 \%$ & $16 \%$ \\
\hline
\end{tabular}




\subsection{Test Lay-Out and Specimen Preparation}

The preparation of the " $\mathrm{PO}$ " cylinders series included the following steps:

- The specimen was treated with a compressed-air jet to remove the dust from the substrate and favor the adhesion of the resin; the surface was dry and regular.

- The lateral surface of the specimen was coated with the epoxy primer and then with the resin in order to provide the fiber adhesion to the substrate.

- A single layer of unidirectional fiber sheet $180 \mathrm{~mm}$ high and $450 \mathrm{~mm}$ long was applied to the surface.

- The fiber sheet was pressed by using a steel roll and covered with a further epoxy resin layer, allowing the sample to be closed with an overlap of about $25 \%$ of the perimeter of its cross-section.

- After $24 \mathrm{~h}$, two axially-oriented (axl-1 and axl-2) and two circumferentially-oriented (rad-1 and rad-2) strain-gauges were applied (see Figure 3). The strain gauges were used to measure the axial and radial deformations of the sample, at the middle height, during the test.

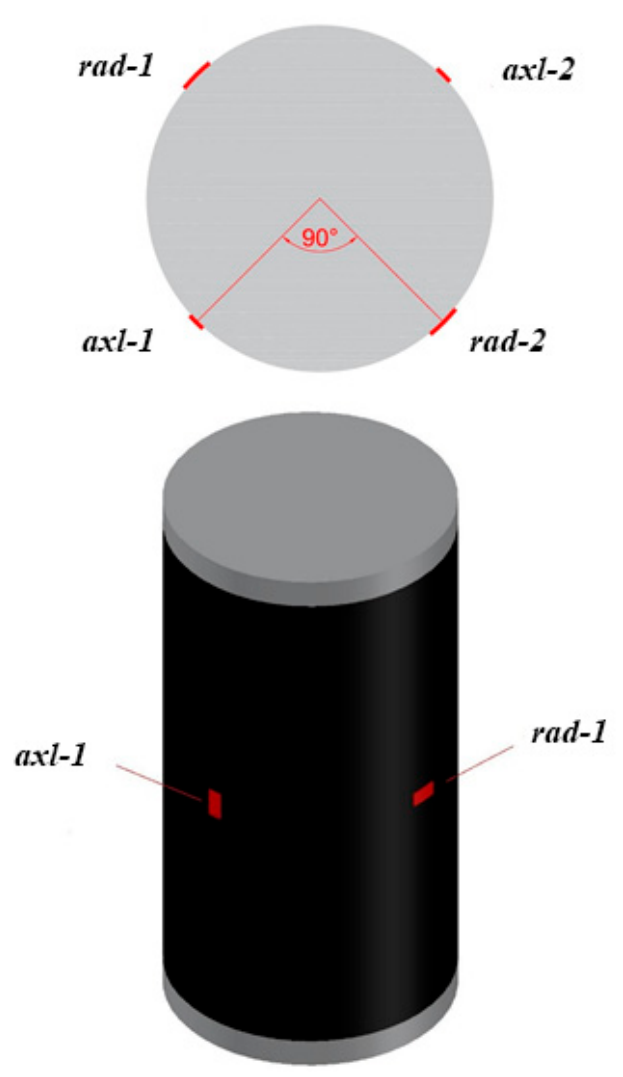

Figure 3. Strain gauges equipment layout.

The preparation of the P20, P50, and P80 specimens was similar to that described for the P0 except for the preliminary phase in which an axial load was applied, before strengthening. A hydraulic jack controlled by a manual pump was used to apply the load, which was measured through an electric load-cell (see Figure 4). The specimens were taken under loading for $120 \mathrm{~h}$, by checking the complete cure of the epoxy matrix, prior to testing. 


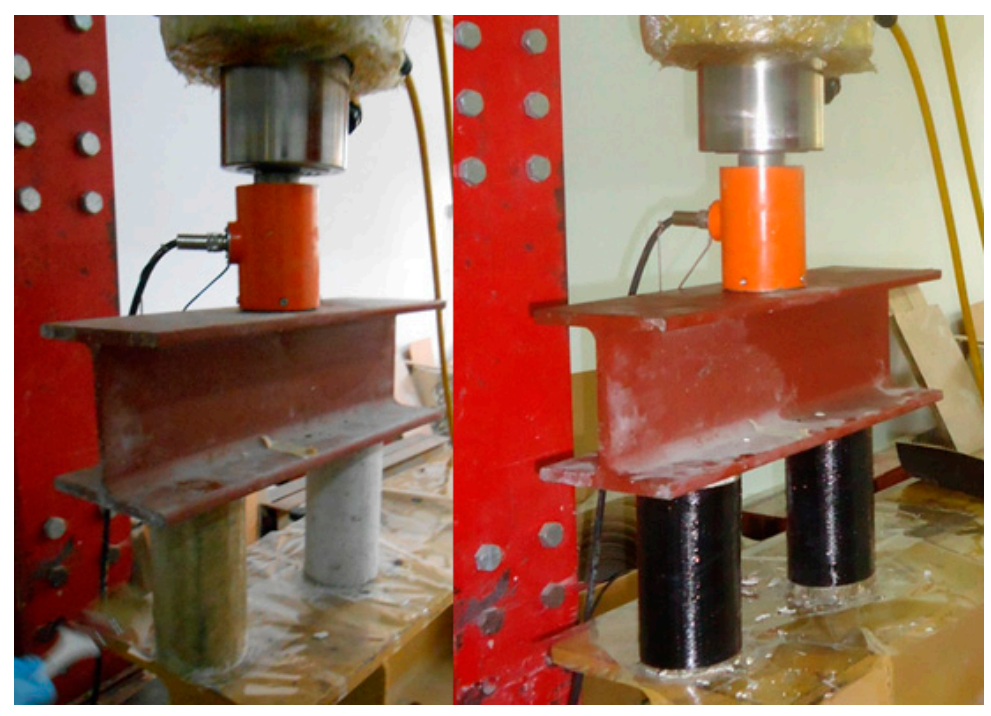

Figure 4. Pre-loaded series specimen preparation: matrix application (left); and CFRP-confinement (right).

\subsection{Test Lay-Out and Specimen Preparation}

Table 2 shows the results of the axial compression tests in terms of average values representing the ultimate axial stress $f_{c c u}$ and strain $\varepsilon_{\mathrm{ccu}}$ and lateral deformation $\varepsilon_{\text {lu }}$. Figure 5 shows experimental curves in forms of ideal bilinear trends. This is useful to distinguish the different behaviors before and after the full activation of FRP-confinement. Figure 6 reports the failure modes observed for all the tested FRP-confined specimens. In all cases, the final stage was accompanied by the tensile rupture of the carbon fibers in one or more regions along the height of the cylinders. The sample named P0_3 showed extreme damage of the concrete core with the hourglass-like shape breaking plan. It was formed due to the frictional forces that develop between the surfaces of the specimen and the press plates, which prevent their deformation.

Table 2. Average values of the tests result and $\mathrm{CoV}$ in brackets.

\begin{tabular}{|c|c|c|c|c|c|c|}
\hline Series & $f_{c c u}(M P a)$ & $\varepsilon_{c c u}(-)$ & $\varepsilon_{l u}(-)$ & $\Delta f_{c c u} \%$ & $\Delta \varepsilon_{c c u} \%$ & $\Delta \varepsilon_{l u} \%$ \\
\hline$U$ & $23.76(3 \%)$ & $0.0071(4 \%)$ & $-0.0015(6 \%)$ & - & - & - \\
\hline P0 & $41.09(5 \%)$ & $0.0128(3 \%)$ & $-0.0026(2 \%)$ & $72.9 \%$ & $80.3 \%$ & $73.3 \%$ \\
\hline P20 & $38.57(4 \%)$ & $0.0124(4 \%)$ & $-0.0025(7 \%)$ & $62.3 \%$ & $74.6 \%$ & $66.7 \%$ \\
\hline P50 & $34.77(8 \%)$ & $0.0120(6 \%)$ & $-0.0024(8 \%)$ & $46.3 \%$ & $69.0 \%$ & $60.0 \%$ \\
\hline P80 & $32.37(10 \%)$ & $0.0099(7 \%)$ & $-0.0020(8 \%)$ & $36.2 \%$ & $39.4 \%$ & $33.3 \%$ \\
\hline
\end{tabular}

The comparison between the average experimental curves allows observing that the constitutive law of the unconfined specimens is superimposed on that of the confined specimens for relatively small stress values, and then it deviates completely for higher axial stress, as expected. The unconfined concrete samples had a pseudo-linear growing trend until extensive cracking occurred, prior to reaching the ultimate strength. The confined concrete samples manifested a pseudo-bilinear behavior in which two phases are recognizable: the first follows the behavior of the unconfined concrete, having an initial elastic modulus comparable to the latter, and the second is affected by the FRP-concrete interaction, in the cracked stage of the expanding concrete core. 


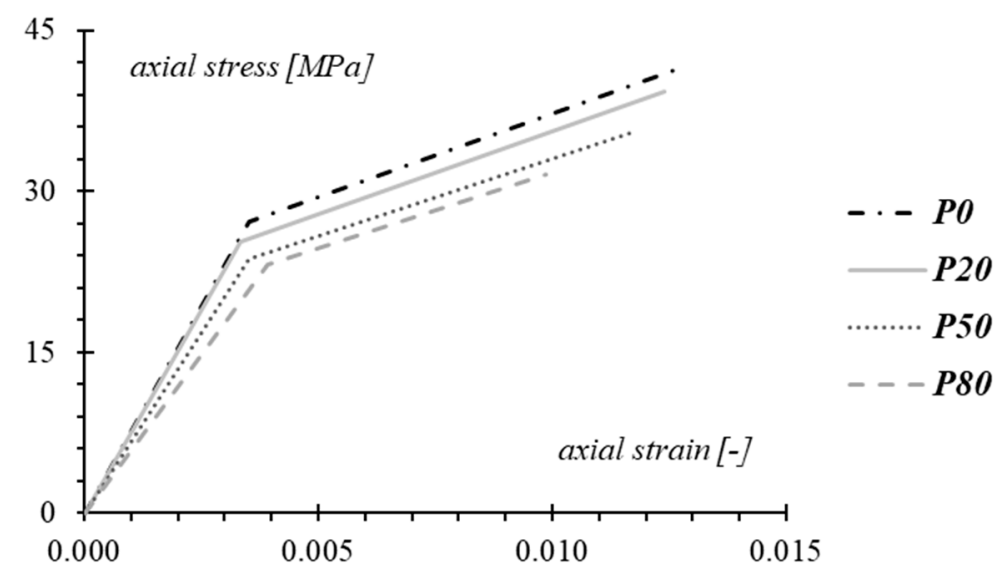

Figure 5. Pre-load effect bilinearization (each curve is the average of five specimens).

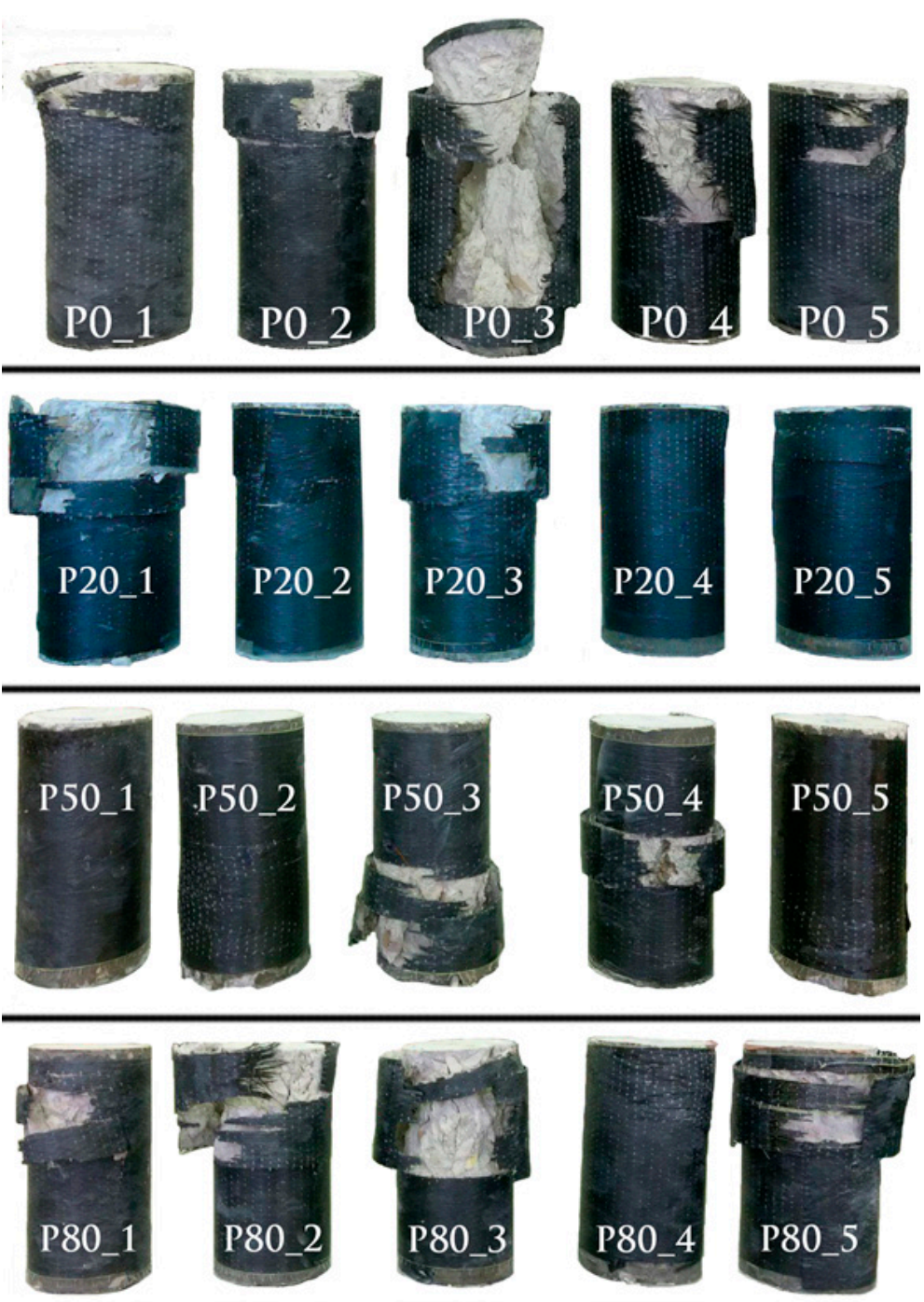

Figure 6. Failure modes of the specimens after testing: $P 0, P 20, P 50$, and $P 80$ from top to bottom.

Another substantial difference can be deducted from the comparison between the experimental curves of the confined specimens subjected to different levels of preload. Specifically, the experimental curves point out that, as the pre-load increases, there is a modest decrease (less than 10\%) of the slope of the second branch in the theoretical bilinear stress vs. strain diagram (see Figure 5). In terms of compressive strength, a reduction is 
evident with increasing pre-loading levels. The differences observed in terms of strength and ultimate strain are related to the fact that, the higher is the pre-load, the greater is the micro-cracking extended within the concrete core, which reduces the capacity to withstand the stresses transmitted during the compression test (see also [69]). Moreover, the pre-load caused micro-damage in the unconfined concrete (see Figure 7), which resulted in a decay of the compressive strength even for very low load level. Moreover, from the average curves in Figure 5, the initial stiffness of $P 80$ specimens appeared to be less than that of unconfined concrete. This can be considered as an effect of the high pre-load applied. As regards the readings of the electrical strain gauges in the hoop direction, unfortunately, the data were highly scattered. The maximum values of the tensile strain were much lower than those of the ultimate tensile strain of the fibers. This was due to the location of the tensile rupture that was different in the failed specimens. Thus, the recorded maximum strains in the central section, where the strain gauges were placed, were not in good accordance with each other.
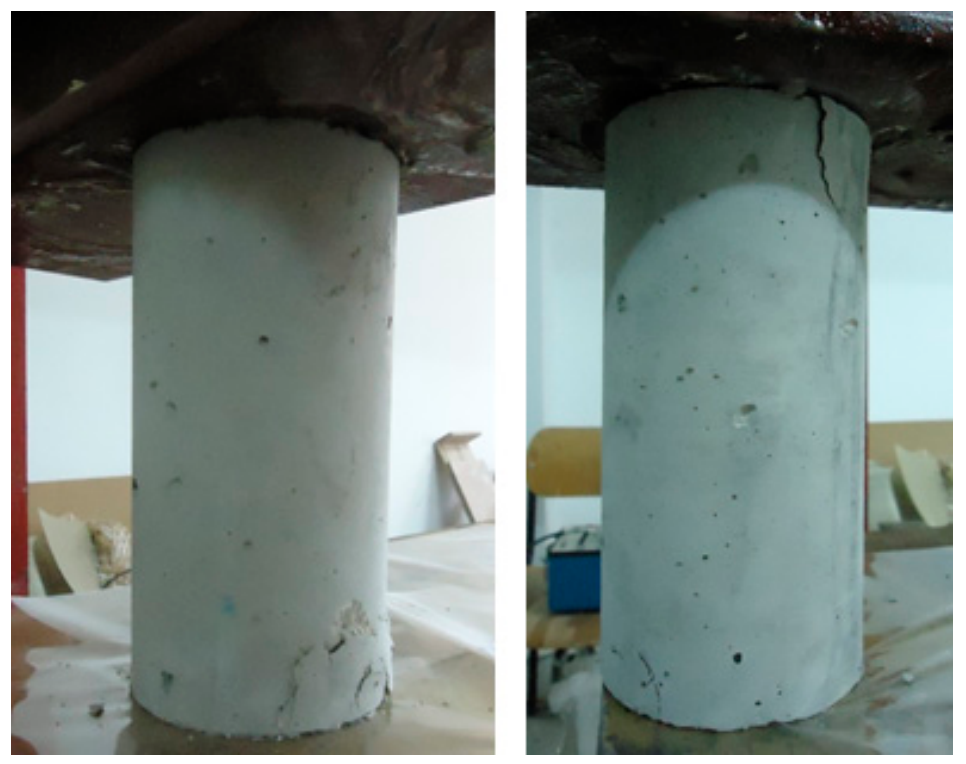

Figure 7. Details of the micro-damage due to pre-loading.

\subsection{Prediction by Means of Available Design-Oriented Models}

A preliminary theoretical versus experimental comparison was assessed by implementing existing analytical models of FRP-confinement, as reported in Table 3, and by considering $\mathrm{P} 0$ specimens. In this comparison, only the effectiveness of confinement was considered, in absence of pre-load before strengthening. In particular, three design codes (i.e., [70-72]) and two further models from scientific literature, reported in [8,73], were applied. All models were found accurate, with the most accurate prediction by ACI 440.2; the other proposals returned an average scatter up to $13 \%$.

Table 3. Experimental versus theoretical comparison for $P 0$ compressive strength.

\begin{tabular}{ccc}
\hline Label & $f_{\text {ccu }}(\mathbf{M P a})$ & $\Delta f_{\boldsymbol{c c u}} \%$ \\
\hline Experimental (P0) & 41.09 & - \\
ACI [70] & 40.87 & $1 \%$ \\
CNR [71] & 38.55 & $7 \%$ \\
Fib [72] & 47.01 & $13 \%$ \\
Cascardi et al. [8] & 37.14 & $10 \%$ \\
Wu and Wang [73] & 36.26 & $12 \%$ \\
\hline
\end{tabular}




\section{Proposed Model}

In this section, we propose a model for the prediction of the pre-load effect on the mechanical response of CFRP-confined concrete under compression loads. The procedure is based on the experimental data illustrated in Figure 5. For this purpose, a modified version of an analysis-oriented model (see [74]), available in the scientific literature, is implemented. The existing model is able to assess the FRP-confined concrete constitutive law based on the theoretical approach reported in [75], in which an increasing value of the external lateral pressure is considered to take into account the FRP-action in the iterative procedure. Thus, the step-lateral deformation $\varepsilon_{l}$ is computed according to Equation (1), once the axial deformation $\varepsilon_{\mathcal{c}}$ and the confining pressure $f_{l}$, are evaluated.

$$
\varepsilon_{l}\left(\varepsilon_{c}, f_{l}\right)=\frac{E_{c} \varepsilon_{c}-f^{\prime}{ }_{c}\left(\varepsilon_{c}, f_{l}\right)}{2 \beta f^{\prime}{ }_{c}\left(\varepsilon_{c}, f_{l}\right)}
$$

where $\varepsilon_{1}$ and $f_{c}^{\prime}$ depend on the axial strain $\varepsilon_{c}$ and the confining pressure fl. A $\beta$-coefficient is also introduced for controlling the initial shape of the stress-strain curve up to the peak point, as reported in Equation (2). This is considered a common approach used in concrete-confinement problems [74].

$$
\beta=\frac{E_{c}}{\left|f^{\prime}{ }_{c 0}\right|}-\frac{1}{\left|\varepsilon_{c 0}\right|}
$$

where $\varepsilon_{c 0}$ is the ultimate strain; $f^{\prime} c 0$ is the axial strength; and $E_{c}$ is the Young's modulus of the unconfined concrete. The Popovics law [76] and the Mander equation [77] are taken as reference for the iterative procedure, as listed in Equations (3)-(6).

$$
f_{c}^{\prime}=\frac{f^{\prime}{ }_{c c} \cdot x \cdot r}{r-1+x^{r}}
$$

with

$$
\begin{gathered}
x=\frac{\varepsilon_{c}}{\varepsilon_{c c}} \\
r=\frac{E_{c}}{E_{c}-E_{s e c}} \\
E_{s e c}=\frac{f_{c c}^{\prime}}{\varepsilon_{c c}}
\end{gathered}
$$

where $f^{\prime} c$ is the concrete stress at a given axial strain, $\varepsilon_{c}$, and $f_{c c}^{\prime}$ is the peak stress of the FRP-confined concrete (Equation (7)). Moreover, the expression of the maximum axial strain $\varepsilon_{\mathcal{~} c}$ is based on the Richart model [78] stated in Equation (8). Finally, Equation (9) predicts the FRP-confining lateral pressure.

$$
\begin{gathered}
\frac{f_{c c}^{\prime}}{f_{c 0}^{\prime}}=2.254 \sqrt{1+7.94 \frac{f_{l}}{f_{c 0}^{\prime}}}-2 \frac{f_{l}}{f_{c 0}^{\prime}}-1.254 \\
\varepsilon_{c c}=\varepsilon_{c 0}\left[1+5\left(\frac{f_{c c}^{\prime}}{f_{c 0}^{\prime}}-1\right)\right] \\
f_{l}=\frac{\alpha \cdot E_{f} \cdot t \cdot \varepsilon_{l}}{2 R}
\end{gathered}
$$

where $\alpha$ is the confining pressure effectiveness coefficient; $E_{f}$ is the Young modulus of the FRP; $t$ is the thickness of the fiber; $\varepsilon_{l}$ is the lateral strain in the FRP; and $R$ is the radius of the circular cross-section of the columns. A schematic representation of the iterative procedure is reported in Figure 8. The starting value of $f_{l}$ is initialized with a try-value, which does not influence the results accuracy at the end of the analytical computation. The iterative procedure runs until the convergence of the lateral confining pressure $f_{l}$ is reached with 
respect to the results of the previous step according to Equation (9). The updated value of the lateral strain $\varepsilon_{l}$ is then computed according to this $f_{l}$-convergence using Equation (1).

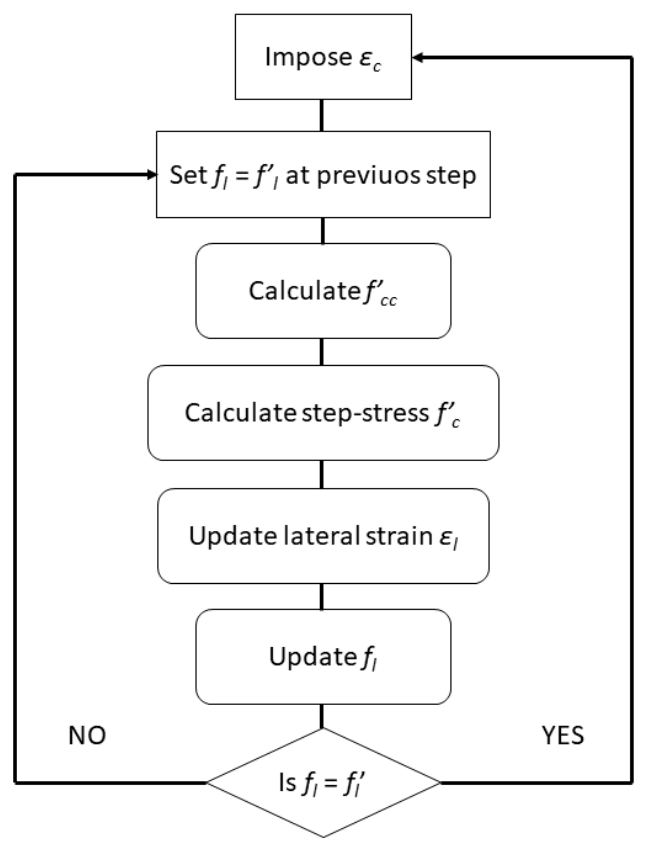

Figure 8. Flow chart of the iterative procedure.

According to the experimental evidence, the pre-load affects both the mechanical proprieties of the unconfined concrete and the FRP-confinement effectiveness. Thus, the proposed model takes into account those aspects, evaluating $f_{c 0}, E_{c 0}$ and $\alpha$, as function of $\sigma_{p}$, by a linear regression analysis (see Figure 9 ). In particular, $\alpha$-value corresponding to $\sigma_{p}$ $=0$ was assumed equal to 0.7 according to [74].

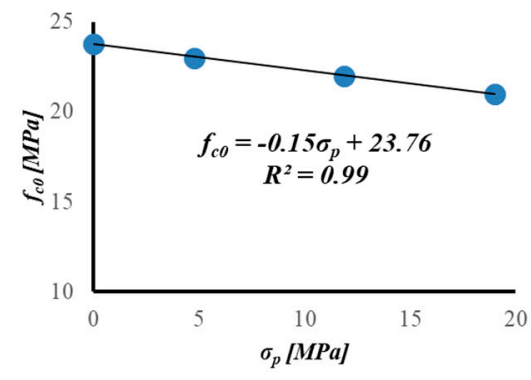

(a)

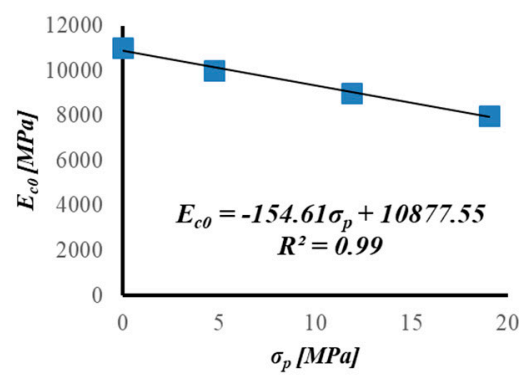

(b)

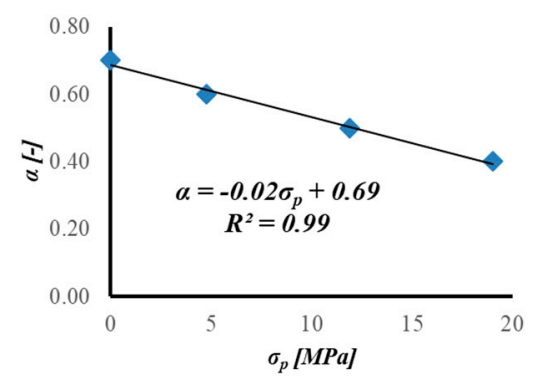

(c)

Figure 9. Analytical interpretation of the pre-load effect: $f_{c 0}(\mathbf{a}) ; \mathrm{E}_{\mathbf{C}}(\mathbf{b}) ;$ and $\alpha(\mathbf{c})$.

\subsection{Prediction by Means of Available Design-Oriented}

A parametric analysis was first performed, as reported in Figure 10. It demonstrates that the proposed model works properly in catching the pre-load effect, since the slope of the curves well reflects the loss of stiffness, which is expected to be caused by the imposed pre-load. An increasing level of the imposed axial pre-stress (from P20 to P80) appears to be detrimental of the mechanical response, as expected in the field and as experienced in the laboratory. The results in terms of stress vs. strain curves are coherently appreciable, as are the results of the axial stress vs. lateral strain curves. In this case, the effect is less evident in terms of stiffness, as also observed in the experimental tests. 


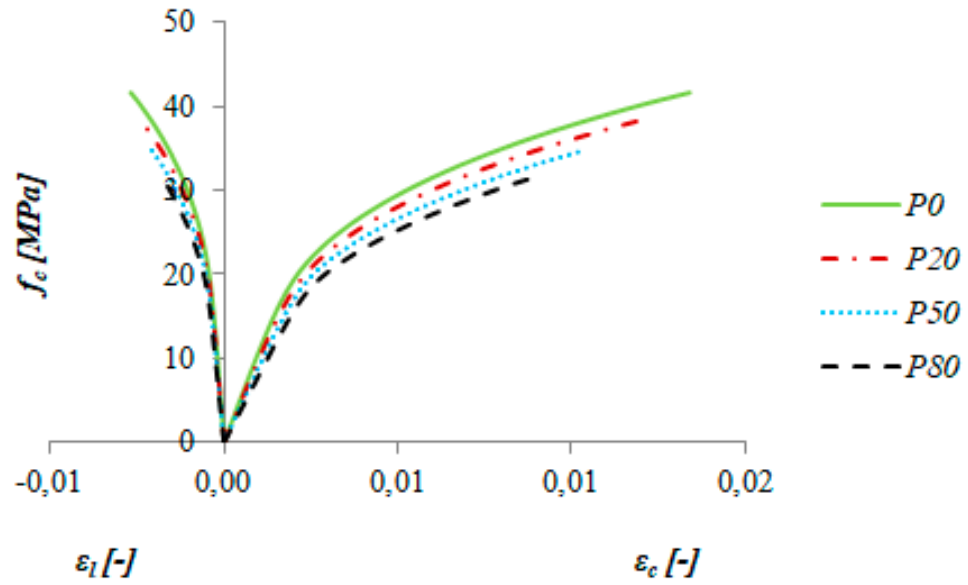

Figure 10. Theoretical pre-load effect.

\subsection{Experimental versus Theoretical Comparison}

In Figure 11, the comparisons of the experimental vs. theoretical diagrams are reported. The actual stress-strain curves refer to the experimental results described in Figure 5. The global behavior appears to be properly caught by the theoretical prediction, as evident from the overlapping of the theoretical (red and continuous) and experimental (black and dotted) lines. Moreover, a further comparison is presented by considering the predictive model that underlies the CNR design code for FRP strengthening [71]. In applying the CNR model, the pre-load conditions are taken into account only by modifying the starting mechanical properties of unconfined concrete. The new properties of unconfined concrete in presence of pre-load $(P 20, P 50$, and $P 80)$ were computed by considering the correlation illustrated in Figure 9a. Table 4 reports the results and the comparison between theoretical and experimental outcomes. It seems that the modified properties of unconfined concrete follow the accuracy trend of the model. Obviously, the CNR model was applied by neglecting the design reduction factors.
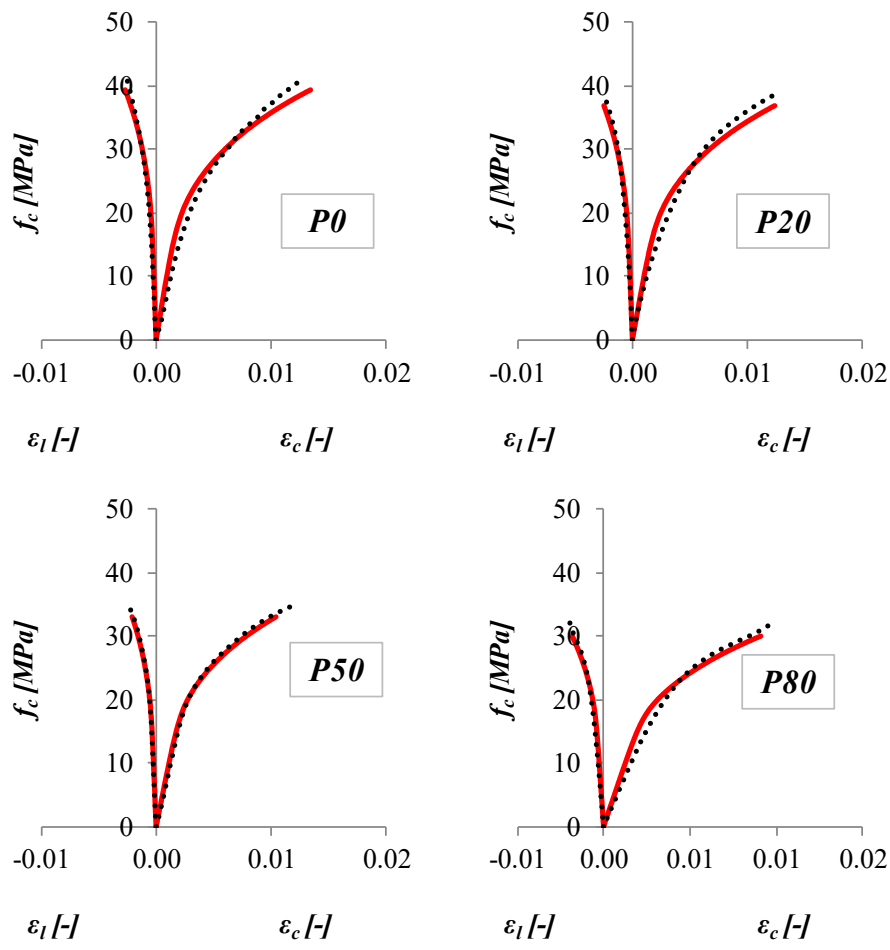

Figure 11. Experimental vs. theoretical comparison (red, theoretical; black, experimental). 
Table 4. Prediction of the CNR model with modified $f_{c 0}$ values.

\begin{tabular}{ccccc}
\hline Label & $\begin{array}{c}f_{c 0}(\mathbf{M P a}) \\
\text { Theoretical Figure } 9 \boldsymbol{a}\end{array}$ & $\begin{array}{c}f_{\text {ccu }}(\mathbf{M P a}) \\
\text { Experimental }\end{array}$ & $\begin{array}{c}f_{\text {ccu }}(\mathbf{M P a}) \\
\text { Theoretical CNR }\end{array}$ & $\boldsymbol{\Delta} f_{\text {ccu }} \%$ \\
\hline P20 & 23.05 & 38.57 & 37.69 & $2 \%$ \\
P50 & 21.98 & 34.77 & 34.77 & $4 \%$ \\
P80 & 20.91 & 32.77 & 32.77 & $7 \%$ \\
\hline
\end{tabular}

\section{Conclusions}

In this paper, the results of an experimental program on CFRP-confined concrete cylinders are discussed with the objective of investigating the pre-load effect. Twenty-five concrete cylinders were prepared and tested under uniaxial compression. Unconfined specimens were tested as reference. The remaining specimens were externally wrapped with unidirectional CFRP sheets under different pre-load levels: $0 \%, 20 \%, 50 \%$, and $80 \%$ of the average ultimate load obtained for unconfined concrete. The experimental results reveal that the presence of a pre-existing load, before jacketing, may influence the final mechanical response of CFRP-confined concrete. By comparing the results of the un-loaded series with the pre-loaded series, important final remarks are reported herein. For low levels of pre-load ( $20 \%$ of the ultimate), the reduction in terms of strength was limited to within $10 \%$, while, when higher levels of pre-load were applied, the strength reduction is more significant, ranging between $26 \%$ and $36 \%$. In terms of ultimate axial strain, the differences were almost negligible until the pre-load level was limited within $50 \%$ of the ultimate. In the case of $P 80$ specimens, the reduction was $40 \%$. In this last case, the initial axial stiffness appeared to be reduced with respect to plain concrete.

Finally, an analytical procedure is proposed to consider and apply the existing theories, by introducing the effect of the pre-loading, before strengthening. This means that an initial axial and radial stiffness should be taken into account when the applied load is high. The analytical predictions show that the mechanical action of the FRP jacket is effective, but the presence of extensive damage avoids exploiting the confinement the same as it would be possible for unloaded columns. The comparison between the analytical predictions and experimental results appeared to be consistent, even if further investigations are considered necessary in order to better validate the proposed theory.

Further investigations are needed to validate the results of this study. Moreover, numerical simulations may be a future direction.

Author Contributions: Conceptualization, F.M.; methodology, F.M.; validation, M.A.A., A.C., and F.M.; formal analysis, A.C.; investigation, A.C.; resources, F.M.; data curation, A.C.; writing-original draft preparation, A.C.; writing-review and editing, M.A.A.; visualization, F.M.; and supervision, M.A.A. All authors have read and agreed to the published version of the manuscript.

Funding: This research received no external funding.

Institutional Review Board Statement: Not applicable.

Informed Consent Statement: Not applicable.

Data Availability Statement: The data presented in this study are available on request from the corresponding author.

Conflicts of Interest: The authors declare no conflict of interest.

\section{References}

1. Bakis, C.E.; Bank, L.C.; Brown, V.; Cosenza, E.; Davalos, J.F.; Lesko, J.J.; Triantafillou, T.C. Fiber-reinforced polymer composites for construction-state-of-the-art review. J. Compos. Constr. 2002, 6, 73-87. [CrossRef]

2. Baasankhuu, B.; Choi, D.; Ha, S. Behavior of Small-Scale Concrete Cylinders in Compression Laterally Confined by Basalt Fiber and PEN Fiber Reinforced Polymer Composites. Int. J. Concr. Struct. Mater. 2020, 14, 1-19. [CrossRef] 
3. Obaidat, Y.T.; Barham, W.S.; Abdelrahman, B.N. Effect of elevated temperature on the bond behavior between near Surface Mounted-Carbon Fiber Reinforced Polymers strips and Recycled Aggregate concrete. Constr. Build. Mater. 2020, 251, 118970. [CrossRef]

4. Kim, Y.J.; Gao, J. Hollow concrete cylinders confined with CFRP: Strength and size effect. Constr. Build. Mater. 2020, $250,118839$. [CrossRef]

5. Hamrat, M.; Bouziadi, F.; Boulekbache, B.; Daouadji, T.H.; Chergui, S.; Labed, A.; Amziane, S. Experimental and numerical investigation on the deflection behavior of pre-cracked and repaired reinforced concrete beams with fiber-reinforced polymer. Constr. Build. Mater. 2020, 249, 118745. [CrossRef]

6. Guler, S.; Ashour, A. Review of current design guidelines for circular FRP-wrapped plain concrete cylinders. J. Compos. Constr. 2015, 20, 04015057. [CrossRef]

7. Cascardi, A.; Micelli, F.; Aiello, M.A. Unified model for hollow columns externally confined by FRP. Eng. Struct. 2016, 111, 119-130. [CrossRef]

8. Cascardi, A.; Micelli, F.; Aiello, M.A. An Artificial Neural Networks model for the prediction of the compressive strength of FRP-confined concrete circular columns. Eng. Struct. 2017, 140, 199-208. [CrossRef]

9. Pachideh, G.; Gholhaki, M. Evaluation of Concrete Filled Steel Tube Column Confined with FRP. J. Test. Eval. 2020, 48 , 4343-4354. [CrossRef]

10. Guo, Y.C.; Xiao, S.H.; Shi, S.W.; Zeng, J.J.; Wang, W.Q.; Zhao, H.C. Axial Compressive Behavior of Concrete-Filled FRP-Steel Wire Reinforced Thermoplastics Pipe Hybrid Columns. Compos. Struct. 2020, 244, 112237. [CrossRef]

11. Wei, Y.; Zhang, Y.; Chai, J.; Wu, G.; Dong, Z. Experimental investigation of rectangular concrete-filled fiber reinforced polymer (FRP)-steel composite tube columns for various corner radii. Compos. Struct. 2020, 244, 112311. [CrossRef]

12. Saberi, H.; Bui, T.Q.; Furukawa, A.; Rahai, A.; Hirose, S. FRP-confined concrete model based on damage-plasticity and phase-field approaches. Compos. Struct. 2020, 244, 112263. [CrossRef]

13. Abdelrahman, K.; El-Hacha, R. Analytical prediction model for circular SMA-confined reinforced concrete columns. Eng. Struct. 2020, 213, 110547. [CrossRef]

14. Jiang, K.; Han, Q.; Bai, Y.; Du, X. Data-driven ultimate conditions prediction and stress-strain model for FRP-confined concrete. Compos. Struct. 2020, 242, 112094. [CrossRef]

15. Ceccato, C.; Teng, J.G.; Cusatis, G. Numerical prediction of the ultimate condition of circular concrete columns confined with a fiber reinforced polymer jacket. Compos. Struct. 2020, 241, 112103. [CrossRef]

16. Dang, Z.; Feng, P.; Yang, J.Q.; Zhang, Q. Axial compressive behavior of engineered cementitious composite confined by fiber-reinforced polymer. Compos. Struct. 2020, 243, 112191. [CrossRef]

17. Zeng, J.J.; Ye, Y.Y.; Gao, W.Y.; Smith, S.T.; Guo, Y.C. Stress-strain behavior of polyethylene terephthalate fiber-reinforced polymerconfined normal-, high-and ultra-high-strength concrete. J. Build. Eng. 2020, 30, 101243. [CrossRef]

18. Pantelides, C.P.; Alameddine, F.; Sardo, T.; Imbsen, R. Seismic retrofit of state street bridge on Interstate 80. J. Bridge Eng. 2004, 9 , 333-342. [CrossRef]

19. Ahmad, S.H.; Khaloo, A.R.; Irshaid, A. Behavior of concrete spirally confined by fiberglass filaments. Mag. Concr. Res. 1991, 43, 143-148. [CrossRef]

20. Khandelwal, S.; Rhee, K.Y. Recent advances in basalt-fiber-reinforced composites: Tailoring the fiber-matrix interface. Compos. Part B Eng. 2020, 192, 108011. [CrossRef]

21. Wang, Q.; Zhu, W.; Fu, F.; Qian, K. Axial Compressive capacity of RC Square Columns strengthened by Prestressed CFRP with RPC pads. Compos. Struct. 2020, 242, 112153. [CrossRef]

22. Carrillo, J.; Valencia-Mina, W.; Bojórquez, E. Compressive performance of square and low-strength concrete columns retrofitted with externally-bonded CFRP. Mater. Today Commun. 2020, 23, 100874. [CrossRef]

23. Zeng, J.J.; Ye, Y.Y.; Guo, Y.C.; Lv, J.F.; Ouyang, Y.; Jiang, C. PET FRP-concrete-high strength steel hybrid solid columns with strain-hardening and ductile performance: Cyclic axial compressive behavior. Compos. Part B Eng. 2020, 190, 107903. [CrossRef]

24. Ren, F.M.; Liang, Y.W.; Ho, J.C.M.; Lai, M.H. Behaviour of FRP tube-concrete-encased steel composite columns. Compos. Struct. 2020, 241, 112139. [CrossRef]

25. Elchalakani, M.; Dong, M.; Karrech, A.; Mohamed Ali, M.S.; Huo, J.S. Circular Concrete Columns and Beams Reinforced with GFRP Bars and Spirals under Axial, Eccentric, and Flexural Loading. J. Compos. Constr. 2020, 24, 04020008. [CrossRef]

26. Faleschini, F.; Zanini, M.A.; Hofer, L.; Pellegrino, C. Experimental behavior of reinforced concrete columns confined with carbon-FRCM composites. Constr. Build. Mater. 2020, 243, 118296. [CrossRef]

27. Zhang, S.; Ye, L.; Mai, Y.W. A study on polymer composites strengthening system for concrete columns. Appl. Compos. Mater. 2000, 7, 125-138. [CrossRef]

28. Campione, G.; Miraglia, N.; Scibilia, N. Compressive behavior of R.C. members strengthened with carbon fiber reinforced plastic layers. In Advances in Earthquake Engineering; Wit Press: Southampton, UK, 2001.

29. Jaffry, S.A.D. Concrete Filled Glass Fibre Reinforced Polyrler (GFRP) Shells Under Concentric Compression. Master's Thesis, Department of Civil Engineering, University of Toronto, Toronto, ON, Canada, 2001.

30. Wang, Y.; Zhang, D. Creep-effect on mechanical behavior of concrete confined by FRP under axial compression. J. Eng. Mech. 2009, 135, 1315-1322. [CrossRef] 
31. Cui, C. Behaviour of Normal and High Strength Concrete Confined with Fibre Reinforced Polymers (FRP). Master's Thesis, University of Toronto, Toronto, ON, Canada, 2009; pp. 1-376.

32. Comert, M.; Goksu, C.; Ilki, A. Towards a tailored stress-strain behavior for FRP confined low strength concrete. In Proceedings of the 9th International Symposium on Fiber Reinforced Polymer Reinforcement for Concrete Structures, Sydney, Australia, 13-15 July 2009.

33. Zîle, E.; Daugevièius, M.; Tamups, V. The effect of pretensioned FRP windings on the behavior of concrete columns in axial compression. Mech. Compos. Mater. 2009, 45, 457. [CrossRef]

34. Aire, C.; Gettu, R.; Casas, J.R.; Marques, S.; Marques, D. Concrete laterally confined with fibre-reinforced polymers (FRP): Experimental study and theoretical model. Mater. Constr. 2010, 60, 19-31. [CrossRef]

35. Benzaid, R.; Mesbah, H.; Nasr Eddine, C. FRP-confined concrete cylinders: Axial compression experiments and strength model. J. Reinf. Plast. Compos. 2010, 29, 2469-2488. [CrossRef]

36. Park, J.H.; Jo, B.W.; Yoon, S.J.; Park, S.K. Experimental investigation on the structural behavior of concrete filled FRP tubes with/without steel re-bar. KSCE J. Civ. Eng. 2011, 15, 337-345. [CrossRef]

37. Rousakis, T.C.; Karabinis, A.I. Adequately FRP confined reinforced concrete columns under axial compressive monotonic or cyclic loading. Mater. Struct. 2012, 45, 957-975. [CrossRef]

38. Ozbakkaloglu, T.; Akin, E. Behavior of FRP-confined normal- and high-strength concrete under cyclic axial compression. $J$. Compos. Constr. 2012, 16, 451-463. [CrossRef]

39. Elsanadedy, H.M.; Al-Salloum, Y.A.; Alsayed, S.H.; Iqbal, R.A. Experimental and numerical investigation of size effects in FRP-wrapped concrete columns. Constr. Build. Mater. 2012, 29, 56-72. [CrossRef]

40. Liang, M.; Wu, Z.M.; Ueda, T.; Zheng, J.J.; Akogbe, R. Experiment and modeling on axial behavior of carbon fiber reinforced polymer confined concrete cylinders with different sizes. J. Reinf. Plast. Compos. 2012, 31, 389-403. [CrossRef]

41. Ravala, R.; Daveb, U. Behavior of GFRP wrapped RC Columns of different shapes. Procedia Eng. 2013, 51, 240-249. [CrossRef]

42. Widiarsaa, I.B.R.; Hadib, M.N.S. Performance of CFRP Wrapped Square Reinforced Concrete Columns Subjected to Eccentric Loading. Procedia Eng. 2013, 54, 365-376. [CrossRef]

43. Song, X.; Gu, X.; Li, Y.; Chen, T.; Zhang, W. Mechanical behavior of FRP-strengthened concrete columns subjected to concentric and eccentric compression loading. J. Compos. Constr. 2013, 17, 336-346. [CrossRef]

44. Vincent, T.; Ozbakkaloglu, T. Influence of concrete strength and confinement method on axial compressive behavior of FRP confined high- and ultra-high-strength concrete. Compos. Part B 2013, 50, 413-428. [CrossRef]

45. Ozbakkaloglu, T.; Vincent, T. Axial Compressive Behavior of Circular High-Strength Concrete-Filled FRP Tubes. J. Compos. Constr. 2013, 18, 04013037. [CrossRef]

46. Ozbakkaloglu, T. Axial compressive behavior of square and rectangular high-strength concrete-filled FRF Tubes. J. Compos. Constr. 2013, 17, 151-161. [CrossRef]

47. Wu, Y.F.; Jiang, J.F. Effective strain of FRP for confined circular concrete columns. Compos. Struct. 2013, 95, 479-491. [CrossRef]

48. Wu, Y.-F.; Jiang, C. Effect of load eccentricity on the stress-strain relationship of FRP-confined concrete columns. Compos. Struct. 2013, 98, 228-241. [CrossRef]

49. Shaia, H.A. Behaviour of Fibre Reinforced Polymer Composite Piles: Experimental and Numerical Study. Ph.D. Thesis, School of Mechanical Aerospace and Civil Engineering, The University of Manchester, Manchester, UK, 2013.

50. Alecci, V.; Briccoli Bati, S.; Ranocchiai, G. Concrete columns confined with CFRP wraps. Mater. Struct. 2014, 47, 397-410. [CrossRef]

51. Yu, T.; Fang, X.L.; Teng, J.G.; Asce, M. FRP-Confined Self-Compacting Concrete under Axial Compression. Mater. Civ. Eng. 2014, 26, 04014082. [CrossRef]

52. Lim, J.C.; Ozbakkaloglu, T. Hoop strains in FRP-confined concrete columns: Experimental observations. Mater. Struct. 2014, 48, 2839-2854. [CrossRef]

53. Lim, J.C.; Ozbakkaloglu, T. Investigation of the Influence of the Application Path of Confining Pressure: Tests on Actively Confined and FRP-Confined Concretes. J. Struct. Eng. 2014, 141, 04014203. [CrossRef]

54. Vincent, T.; Ozbakkaloglu, T. Influence of Slenderness on Stress-Strain Behavior of Concrete-Filled FRP Tubes: Experimental Study. J. Compos. Constr. 2015, 19, 04014029. [CrossRef]

55. Saleem, S.; Hussain, Q.; Pimanmas, A. Compressive Behavior of PET FRP-Confined Circular, Square, and Rectangular Concrete Columns. J. Compos. Constr. 2016, 21, 04016097. [CrossRef]

56. Demers, M.; Neale, K. Confinement of reinforced concrete columns with fibre-reinforced composite sheets-An experimental study. Can. J. Civ. Eng. 1999, 26, 226-241. [CrossRef]

57. Ilki, A.; Kumbasar, N. Behavior of damaged and undamaged concrete strengthened by carbon fiber composite sheets. Struct. Eng. Mech. 2002, 13, 75-90. [CrossRef]

58. Liu, H.; Liao, W.; Tseng, L.; Lee, W.-H.; Sawada, Y. Compression strength of pre-damaged concrete cylinders reinforced by non-adhesive filament wound composites. Compos. Part A Appl. Sci. Manuf. 2004, 35, 281-292. [CrossRef]

59. Shi, D.; He, Z. Short-term axial behavior of preloaded concrete columns strengthened with fiber reinforced polymer laminate. In Computational Structural Engineering; Springer: Dodrecht, The Netherlands, 2009; pp. 1089-1098.

60. Cui, C.; Sheikh, S.A. Experimental study of normal and high-strength concrete confined with fiber-reinforced polymers. J. Compos. Constr. 2010, 14, 553-561. [CrossRef] 
61. Erdil, B.; Akyuz, U.; Yaman, I.O. Mechanical behavior of CFRP confined low strength concretes subjected to simultaneous heating-cooling cycles and sustained loading. Mater. Struct. 2012, 45, 223-233. [CrossRef]

62. Dalgic, K.D.; Ispir, M.; Binbir, E.; Ilki, A. Effects of pre-damage on axial behavior of CFRP jacketed non-circular members. In Proceedings of the Conference on Civil Infrastructure Based on Polymer Composites-CECOM, Krakow, Poland, 22-23 November 2012.

63. Ranolia, K.V.; Thakkar, B.K.; Rathod, J.D. Effect of Different Patterns and Cracking in FRP Wrapping on Compressive Strength of Confined Concrete. Procedia Eng. 2013, 51, 169-175. [CrossRef]

64. Demir, C.; Kucukkapili, A.; Doyrangol, D.; Ilki, A. The effects of loading rate and duration on the axial behavior of low-strength and medium-strength noncircular concrete members confined by fiber-reinforced polymer sheets. Polymers 2014, 6, 1685-1704. [CrossRef]

65. Pan, Y.; Guo, R.; Li, H.; Tang, H.; Huang, J. Analysis-oriented stress-strain model for FRP-confined concrete with preload. Compos. Struct. 2017, 166, 57-67. [CrossRef]

66. Ma, C.K.; Chin, S.S.Y.; Apandi, N.M.; Awang, A.Z.; Omar, W. Effects of Pre-Damaged Level on Confined HSC Columns. In MATEC Web of Conferences; EDP Sciences: Les Ulis, France, 2017; Volume 103, p. 02007.

67. American Society for Testing and Materials. Standard Test Method for Compressive Strength of Cylindrical Concrete Specimens; C39-86; ASTM International: West Conshohocken, PA, USA, 1997; pp. 20-24.

68. American Society for Testing and Materials, ASTM Committee D-30 on Composite Materials. Standard Test Method for Tensile Properties of Polymer Matrix Composite Materials; ASTM International: West Conshohocken, PA, USA, 2008.

69. Pan, Y.; Rui, G.; Li, H.; Tang, H.; Xu, L. Study on stress-strain relation of concrete confined by CFRP under preload. Eng. Struct. 2017, 143, 52-63. [CrossRef]

70. Committee 440, American Concrete Institute. Guide for the Design and Construction of Externally Bonded FRP Systems for Strengthening Concrete Structures: ACI 440.2 R-02; American Concrete Institute: Indianapolis, IN, USA, 2002.

71. National Research Council. CNR-DT 200 R1/2013 Guide for the Design and Construction of Externally Bonded FRP System for Strengthening Existing Structures; Advisory Committee on Technical Recommendations for Construction, CNR National Research Council: Roma, Italy, 2013.

72. Fédération Internationale du Béton (fib). Externally Bonded FRP Reinforcement for RC Structures; Bulletin No. 14; Fib: Lausanne, Switzerland, 2001.

73. Wu, Y.F.; Wang, L.M. Unified strength model for square and circular concrete columns confined by external jacket. J. Struct. Eng. 2009, 135, 253-261. [CrossRef]

74. Spoelstra, M.R.; Monti, G. FRP-confined concrete model. J. Compos. Constr. 1999, 3, 143-150. [CrossRef]

75. Pantazopoulou, S.J.; Mills, R.H. Microstructural aspects of the mechanical response of plain concrete. ACI Mat. J. 1995, 92, 605-616.

76. Popovics, S. A numerical approach to the complete stress-strain curve of concrete. Cem. Concr. Res. 1973, 3, 583-599. [CrossRef]

77. Mander, J.B.; Priestley, M.J.N.; Park, R. Theoretical stress-strain model for confined concrete. ASCE J. Struct. Eng. 1988, 114, 1804-1826. [CrossRef]

78. Richart, F.E.; Brandtzaeg, A.; Brown, R.L. A Study of the Failure of Concrete Under Combined Compressive Stresses; Engineering Experiment Station, College of Engineering, University of Illinois at Urbana Champaign: Urbana and Champaign, IL, USA, 1928. 